\title{
The Effect of River Discharge and Winds on the Interannual Variability of the Pink Shrimp Farfantepenaeus paulensis Production in Patos Lagoon
}

\author{
Osmar O. Möller Jr. • Jorge Pablo Castello • \\ Ana Carolina Vaz
}

Received: 4 June 2008 /Revised: 2 December 2008 / Accepted: 18 April 2009/Published online: 5 May 2009

(C) Coastal and Estuarine Research Federation 2009

\begin{abstract}
The Patos Lagoon estuary is an important environment for the life cycle of many species, including the pink shrimp Farfantepenaeus paulensis. This area acts as a nursery ground for the shrimp larvae, which are spawned in a coastal area and transported into the lagoon during spring and early summer (September to December). Harvesting of shrimp occurs from January to May, and yields have varied from around 1,000 to 8,000 tons year ${ }^{-1}$. This study is based on analysis of river discharge, pink shrimp catches, and wind velocity time series from 1964 to 2004. Negative correlation between pink shrimp catches and river runoff reflects the influence of discharge on the lagoon circulation and, consequently, on the intrusion of salt water and larvae. When river discharge is below average, landward currents forced by SW winds can enhance larval transport into the estuarine area, leading to an increase in pink shrimp captures. Above average river
\end{abstract}

O. O. Möller Jr. $(\square)$

Núcleo de Oceanografia Física, Instituto de Oceanografia,

Universidade Federal do Rio Grande (FURG),

Campus Carreiros,

96201-900 Rio Grande, RS, Brazil

e-mail: dfsomj@furg.br

J. P. Castello

Laboratório de Recursos Pesqueiros Pelágicos,

Instituto de Oceanografia,

Universidade Federal do Rio Grande (FURG),

Campus Carreiros,

96201-900 Rio Grande, RS, Brazil

e-mail: docjpc@furg.br

A. C. Vaz

Department of Oceanography, University of Hawaii at Manoa,

1000 Pope Rd., Marine Science Building,

Honolulu, HI 96822, USA

e-mail: vaz@hawaii.edu input would force a seaward flow that works as a barrier to ingress of larvae. This is unusual when compared to many other estuarine systems, and the main factor that accounts for this behavior is the morphology (choking) of Patos Lagoon. Interannual variability related to El Niño/Southern Oscillation events also influence pink shrimp production in this area. Low/high shrimp catches are related to El Niño (flood)/La Niña (drought) events. Wind can also impact production through its effect on the southward displacement of larvae from the spawning area. Long-term trends indicate an increase in river discharge around $20 \mathrm{~m}^{3} \mathrm{~s}^{-1} \mathrm{year}^{-1}$ and a decrease in shrimp catches on the order of 57 tons year $^{-1}$.

Keywords Coastal lagoon $\cdot$ River effect $\cdot$ Morphological role - Wind action - Shrimp production .

Interannual variability

\section{Introduction}

The Patos Lagoon (PL) estuary (Fig. 1) is an important environment for the life cycle of many fish, mollusk, and crustacean species, notably because of its role as a shelter area that allows their development from early larval stages (Castello 1985; Vieira and Castello 1996; Muelbert and Weiss 1991). The pink shrimp Farfantepenaeus paulensis is an estuarine-dependent organism which uses the estuary as a nursery ground and constitutes the most important resource for artisanal fishing in the region. The exploitation of this species is intensified during summer and autumn (Jan/Feb to May). The primary gear used by artisanal fishermen is a fixed stownet equipped with lights to attract shrimp at night and placed in shallow waters. This efficient gear allows for only a few shrimp to escape capture (Kalikoski et al. 2002). The PL stock is not subject to 
Fig. 1 a Inset showing the study area denoted by the ellipsis with respect to the Brazilian coastline. b An overview of the study area including the hydrographical basin of Patos Lagoon. $S G C$ is the São Gonçalo Channel and $S L S$ indicates the city of São Lourenço do Sul. c A schematic detail of the estuarine area denoting the reduction in the cross-sectional area towards the entrance and the two $4 \mathrm{~km}$ long jetties built in the early twentieth century

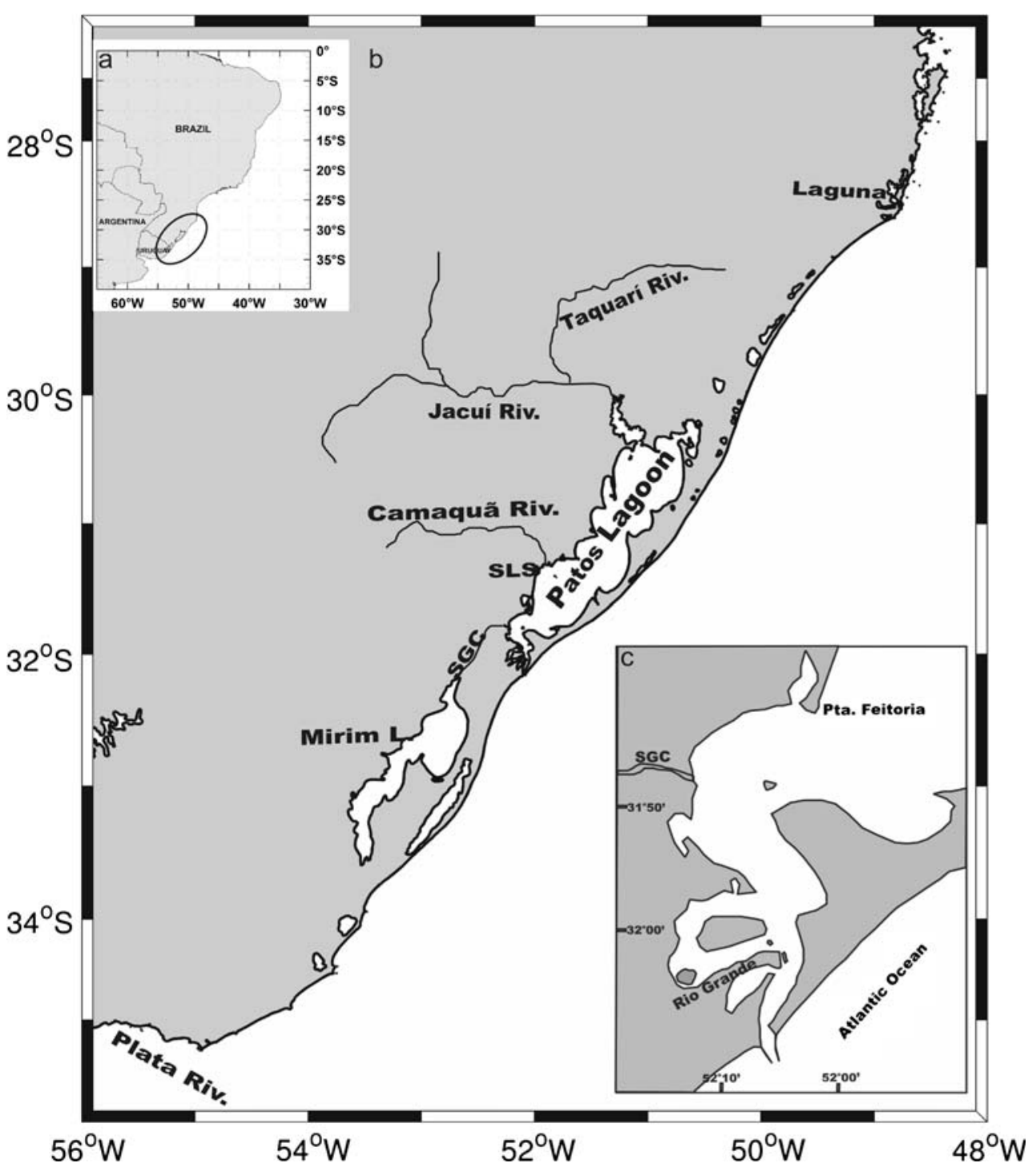

industrial fishing in both the estuarine and adjacent oceanic areas (D'Incao et al. 2002).

Absence of pink shrimp adults on shelf waters between $32^{\circ}$ and $29^{\circ} \mathrm{S}$ (Zenker and Agnes 1977) suggests that pink shrimp standing stock in the PL is part of a metapopulation, the source of which is believed to be located between $27^{\circ}$ and $29^{\circ} \mathrm{S}$ in the coastal area of Santa Catarina State (D'Incao 1991; Delevedove 1996). Therefore, fishery activities in the PL are not considered to exert any impact upon the source population, as concluded by D'Incao et al. (2002).

The pink shrimp larvae are passively transported into the estuary by currents during spring and early summer, with a peak in November-December (Castello and Möller 1978; D'Incao 1991). From October to April, megalopa larvae of pink shrimp are present in the channel waters close to the estuary entrance (Calazans, personal communication). They reach shallow small inlets or embayments, where dense seagrass vegetation provides favorable conditions for larvae to finish their metamorphosis. By autumn (April/May), the maturity gonadal process has already started in most females, triggering their reproductive migration back to the ocean (D'Incao 1991; Valentini et al. 1991).

Artisanal fishing pressure remained approximately constant along time (Haimovici et al. 2006); therefore, the pronounced oscillations in the capture series should relate to environmental factors. Local physical processes are known to exert influence on the life cycle and survival of many estuarine species of the PL. For instance, Castello and Möller (1978) found a strong negative correlation between precipitation in the hydrographic basin of PL and pink shrimp catches from 1967 to 1976. High freshwater discharges act as a physical barrier not allowing salt water intrusion into the estuary (Castello and Möller 1978; Abreu and Castello 1997; Möller and Castaing 1999). The fast decrease in salinity during heavy freshwater runoff may be a lethal factor for shrimp larvae since, according to Marchiori (1983), they do not tolerate salinity lower than 
3. Freshwater input in the PL can affect recruitment, immigration and emigration patterns of estuarine species (Garcia et al. 2001), and meteorological events alter temporal and spatial distributions of several icthyoplankton species in the area (Muelbert and Weiss 1991).

The aim of this paper is to amplify Castello and Möller (1978) research through the analysis of river discharge and pink shrimp catches series that cover 40 years (1964-2005), a period remarkably longer than the 9 years used in the previous work. River runoff was preferable to precipitation because it is a better proxy of estuarine residual circulation. The main questions to be answered in the present work are (a) if shrimp catches vary accordingly to changes in river discharge, (b) if interannual climatological events, such as El Niño and La Niña, exert any influence on the PL shrimp production, and (c) if winds present any effect on the southward transport of larvae from the spawning areas to their nursery grounds in PL.

\section{Study Area}

Placed in southern Brazil between $30^{\circ}$ and $32^{\circ} \mathrm{S}$, the Patos Lagoon (Fig. 1) occupies an area of approximately $10,000 \mathrm{~km}^{2}$ and is the largest choked coastal lagoon in the world (Kjerfe 1986). It is $250 \mathrm{~km}$ long and $40 \mathrm{~km}$ wide in average, but it is connected to the Atlantic Ocean through a long $(20 \mathrm{~km})$ and very narrow channel $(\sim 1 \mathrm{~km}$ wide) that is dredged to attain a depth of $14 \mathrm{~m}$.

The lagoon and the adjacent coastal area are one of the most important fishery sites of southern Brazil (Garcia et al. 2001), where 3,500 artisanal and industrial fishermen are permanently or temporarily involved in fisheries activities (Haimovici et al. 1996; Reis and D'Incao 2000). More than 20 years ago, the secondary production reached an average of $182.8 \mathrm{~kg} \mathrm{ha}^{-1}$ year $^{-1}$ (Castello 1985). Although there are no recent figures of secondary production, fisheries production has shown a decline for the last 20 years (Haimovici et al. 2006).

Like most choked coastal lagoons, the PL circulation is mainly driven by winds and freshwater runoff, since tides are of secondary importance for this type of estuarine system (Kjerfe 1986; Möller et al. 2001; Möller et al. 2007). In the study area, northeasterly winds are predominant throughout the year, although during autumn and winter, southwesterly winds are more frequent (Möller et al. 2001).

The main tributary rivers of the PL, Jacuí, Taquarí, Camaquã, and São Gonçalo channel (see Fig. 1 for reference) follow a typical pattern of temperate areas presenting high discharge values in late winter and early spring and low to moderate runoff during summer and autumn. The mean river discharge is around $2,400 \mathrm{~m}^{3} \mathrm{~s}^{-1}$
(Vaz et al. 2006). Large interannual variations ranging from $500 \mathrm{~m}^{3} \mathrm{~s}^{-1}$ up to $12,000 \mathrm{~m}^{3} \mathrm{~s}^{-1}$ are observed and can be associated with El Niño/Southern Oscillation (ENSO) events (Vaz et al. 2006). Studies carried out by Kousky and Cavalcanti (1984), Ropelewski and Halpert (1987), Moron et al. (1995), and Grimm et al. (1998; 2000) found a strong correlation between positive/negative precipitation anomalies in southern Brazil and El Niño/La Niña events. The same trend was observed for the streamflow of the Uruguay River (Mechoso and Pérez-Iribarren 1992) and for PL tributaries (Vaz et al. 2006).

Studies carried out by Möller (1996) and Möller et al. (2001) demonstrated that PL is a river-dominated system. In periods when river discharge $(Q)$ ranges from low to moderate $\left(Q<2,400 \mathrm{~m}^{3} \mathrm{~s}^{-1}\right)$, the wind plays the main role in the dynamics of this lagoon at synoptical timescales. In this case, the exchanges between PL and the adjacent ocean are mainly driven by barotropic pressure gradients forced by the combined effects of local and remote winds (Möller et al. 2001). Seaward and landward flows are the result of NE and SW winds, respectively. Reversals in the wind field occur due to the passage of meteorological fronts in time intervals ranging from 3 to 15 days (Möller et al. 2001). However, during the seasonal flood period, only very strong winds can reverse the seaward flow, and the water in the lagoon can remain fresh for several months (Möller and Castaing 1999).

\section{Data and Methods}

Time series used in this paper are presented in Fig. 2. Discharge data for Jacuí, Taquarí, and Camaquã rivers (Fig. 2a) were obtained at the Brazilian National Agency of Waters (Agência Nacional de Águas 2007, hidroweb.ana. gov.br), covering the period between 1964 and 2004. Total river discharge is given by summing runnof values of these three rivers and represents about $70 \%$ of the hydrological basin contribution into the PL. It will be used as a proxy in this study because there is no data available for the São Gonçalo channel that connects the Patos and Mirim lagoons (see Fig. 1 for reference).

ENSO events are represented by the Southern Oscillation Index (SOI, dotted gray line in Fig. 2a), which indicates its intensity and phase. It is defined as a difference between deviations from normal atmospheric pressure in two stations located in the Tropical Pacific East and West (Kousky and Cavalcanti 1984). Negative or positive values of this index are indicators of El Niño or La Niña, respectively. SOI series from 1964 to 2004 were obtained from the Australian Bureau of Meteorology website (2007; www.bom.gov.au/climate/current/soihtm1.shtml).

The wind stress (not shown) used in this paper is the same data set used by Piola et al. (2005) to study processes 
Fig. 2 Time series of: a monthly river discharge (black) and SOI (dotted gray) where negative values indicate El Niño events; b monthly pink shrimp catches
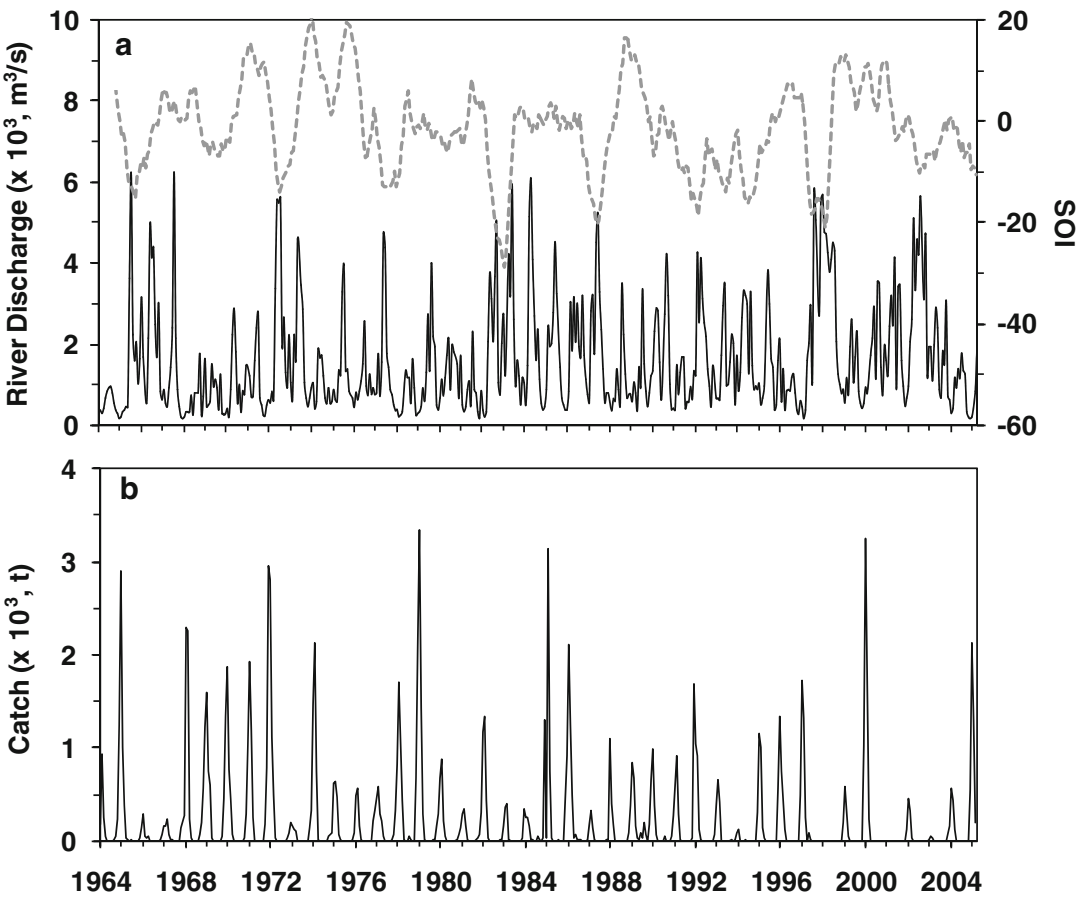

affecting the meridional displacement of the Plata River Plume. This series was expanded to match the time limit of river and pink shrimp catch data. It consists of global reanalysis from National Centers for Environmental Prediction (Kistler et al. 2001) and the European Centre for Medium-Range Weather Forecasts (Trenberth et al. 1989) and was validated with wind measurements from Chui $\left(34^{\circ} \mathrm{S}\right)$. The wind stress was decomposed in cross-shore and along-shore components. Considering the dynamics of the region and objectives of this study, just the alongshore component will be considered.

Pink shrimp catch data, from 1965 to 2005 (Fig. 2b), was provided by the Rio Grande unit of the National Institute of Environmental Protection (IBAMA). According to Brazilian law, local fishermen must report their captures to IBAMA. Type and number of gear used is not officially recorded. However, field observation indicates that stownet is the most common gear used to fish shrimp in the region (Kalikoski et al 2002). Thus, our series correspond to the landings of shrimp mainly fished with a passive fishing gear in the area between the mouth of PL and the city of São Lourenço do Sul (see Fig. 1, SLS). Since the shrimp fishing effort in PL have not been determined, it is impossible to calculate the catch per unit of effort or the catch/effort $(C / f)$ rate which should be a better indicator of shrimp abundance.

In order to establish the period of the year when continental runoff has the closer relationship with pink shrimp captures, a variable named mean river discharge (MRD) was calculated for different month intervals. The initial month of this interval varied from August to
November and the ending month from December to May (of the subsequent year). The first MRD series was calculated as the mean river discharge from August to December. The next MRD was increased with the inclusion of the following month (Jan), and the process would continue until the month of May. In the second round, river discharge data started in September and so on. This procedure resulted in $30 \mathrm{MRD}$ series that were correlated at a 95\% level with the total shrimp catches (TSC), which represents the sum of declared landings from January to May. For correlation purposes, both MRD and TSC series had their time trends removed.

The MRD values corresponding to the period that presented highest correlation with TSC were then divided into three classes according to their magnitude: low $\left(\mathrm{MRD}<1,000 \mathrm{~m}^{3} \mathrm{~s}^{-1}\right)$, regular $\left(1,000 \mathrm{~m}^{3} \mathrm{~s}^{-1}<\mathrm{MRD}<\right.$ $2,000 \mathrm{~m}^{3} \mathrm{~s}^{-1}$ ), and high (MRD $\left.>2,000 \mathrm{~m}^{3} \mathrm{~s}^{-1}\right)$. Based on the classification used by Grimm et al. $(1998 ; 2000)$ and Berlato and Fontana (2003), the period when the best correlation between MRD and TSC was found was then classified according to the type of ENSO event: El Niño, La Niña, or Neutral (weak events of El Niño or La Niña). Using this criterion, a bifactorial analysis of variance (ANOVA) was performed to verify a possible interaction between these variables. Pink shrimp catches were then categorized by the magnitude of river discharge and phase of ENSO event. This type of analysis also indicated the standard deviation and the standard error.

In order to evaluate the possible effect of the wind, a variable named mean wind index (MWI) was defined as the longitudinal wind stress mean calculated for the same 
period where the highest correlation between MRD and TSC was found.

Spectral analyses were carried out in order to detect the dominant periods in all the obtained time series. The method followed Emery and Thomson (1997), and the density of the spectral energy (f.Syy) was calculated as a function of the $f$ logarithm to preserve variance. To reduce the inherent error of the Fast Fourier Transform, the time series were divided in three segments, which were smoothed with a Hamming window that overlaps $50 \%$ over the length of the time series. This procedure increased the degrees of freedom of the analysis (Ramp et al 1997).

\section{Results}

\section{River and Wind Effects}

Monthly mean river discharges calculated from the sum of Jacuí, Taquarí, and Camaquã river flows (Fig. 2a) show large fluctuations, from 200 to $6,000 \mathrm{~m}^{3} \mathrm{~s}^{-1}$. During specific years, such as 1965/1966, 1972/1973, 1977, $1982 / 1983,1997 / 1998$, and $2001 / 2002$, river discharge is three to four times greater than annual mean average $\left(1,588 \mathrm{~m}^{3} \mathrm{~s}^{-1}\right.$, Table 1). These situations are related to negative SOI values (El Niño). Low river discharge periods are usually associated with positive SOI (La Niña), with few exceptions (1967 and 1984; Fig. 2a).

The general pattern in the along-shore wind component time series (not shown) are positive (northeastward) mean values during winter and negative (southwestward) mean values during summer.

Pink shrimp monthly catches (Fig. 2b) present a peak in the first semester of the year. The highest values are usually observed for March and April, and large variations among consecutive years can also be noticed. Monthly landings of pink shrimp vary from few tons to 3,000 tons, as observed in 1972, 1979, 1985, and 2000. In average, 2,760 tons of shrimp are caught per year (Table 1).

When these series were transformed to MRD, TSC, and SOI, the bifactorial ANOVA test indicated that there is no interaction between the class of river discharge and the type of ENSO event when analyzing TSC $(p=0.17)$. Then it is

Table 1 Mean and standard deviation values for: the annual river discharge, the mean river discharge from Sept. to Dec. (MRD), and the total catches of pink shrimp (TSC)

\begin{tabular}{lrr}
\hline Variable & Mean & $\begin{array}{r}\text { Standard } \\
\text { deviation }\end{array}$ \\
\hline Annual mean river discharge $\left(\mathrm{m}^{3} \mathrm{~s}^{-1}\right)$ & 1,588 & 695 \\
Mean river discharge-Sep-Dec $\left(\mathrm{MRD}, \mathrm{m}^{3} \mathrm{~s}^{-1}\right)$ & 1,684 & 853 \\
Pink shrimp catches (TSC, ton) & 2,760 & 2,182 \\
\hline
\end{tabular}

possible to perform independent analysis concerning the effects of MRD and ENSO events on shrimp catches.

The correlation analysis performed between the detrended time series of MRD and TSC resulted in coefficients ranging from -0.57 to -0.67 . The highest correlation $(p<0.01)$ corresponds to the MRD from September to December. This inverse relationship denotes the importance of river discharge as one of the controlling factors for shrimp landings, with high/low discharge values leading to low/high catches. This is evident through the analysis of Fig. 3, which displays time series of MRD from September to December and TSC from January to May of the following year. Low catches of shrimp generally coincides with high discharge events, which usually occurs during El Niño years. On the other hand, high values are observed when river discharge is well below average. However, for some of the observations, low/high shrimp catches do not correspond to the opposite river discharge intensity. This is the case for the periods from 1975 to 1976, 1980 to 1982, and 1988-1989, all of which correspond to La Niña. It was also observed from 1991 to 1995, a period of El Niño. In order to discriminate the effect of river discharge, box-plots of TSC categorized by MRD were used. Figure 4 shows that the mean of TSC decreases from low $\left(\mathrm{MRD}<1,000 \mathrm{~m}^{3} \mathrm{~s}^{-1}\right.$ ) to high (MRD> $2,000 \mathrm{~m}^{3} \mathrm{~s}^{-1}$ ) river discharge and that it also presents lower standard deviation with respect to low and regular. Regular river discharge $\left(1,000 \mathrm{~m}^{3} \mathrm{~s}^{-1}<\mathrm{MRD}<2,000 \mathrm{~m}^{3} \mathrm{~s}^{-1}\right)$ presents the larger standard deviation. From the ANOVA results, we can infer that the mean of TSC for low and high discharges are significantly different $(p<0.01)$.

To test the likelihood of winds to impact pink shrimp catches, a correlation analysis between MWI and TSC data was carried out. Figure 5 shows the temporal plots of MWI and TSC where the negative significant relationship $(r=-0.27 ; p<0.05)$ between the variables is clearly observed. Catches above and below average are related to occurrence of NE and SW winds, respectively. Through a comparative analysis of the results in Figs. 3 and 5, it can be observed that extremely high values of TSC are usually associated with a combination of small MRD and negative MWI (NE winds). Then, as depicted from the data, the occurrence of favorable river discharge conditions by itself cannot guarantee a high TSC in PL. The TSC values registered are low when MRD is below average but the MWI is positive, a situation that occurred from 1975 to 1976, 1980 to $1982,1988-1989$, and 1991 to 1994 . These years were characterized by the predomination of positive MWI (SW winds). A stepwise regression performed between TSC and MRD increased from -0.67 to -0.72 $(p<0.05)$ when MWI was included. It highlights the importance of the wind effect on the successful larval transport to the PL entrance area. 


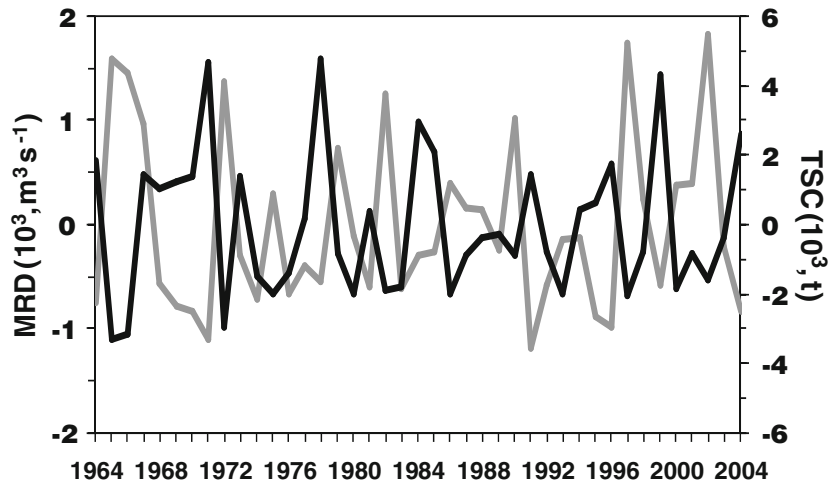

Fig. 3 Time series of mean river discharge from September to December (MRD, gray) and total shrimp catches (TSC, black). Trend was removed in both series

Interannual and Longer-Term Variability

Figure 6 shows TSC classified accordingly to the type of ENSO event. An ANOVA test indicated that the TSC mean presents significant differences $(p<0.01)$ for El Niño and La Niña type of events. These results make possible to associate lower/higher TSCs to El Niño/La Niña years. The sharp trend existent between heavier river flow associated with El Niño years and lower catches is also confirmed by the lower standard deviation. During La Niña, even though the trend of decreased river flow associated with increased TSC is clear, the standard deviations are large. One more time, it is possible to associate this decrease in TSC under

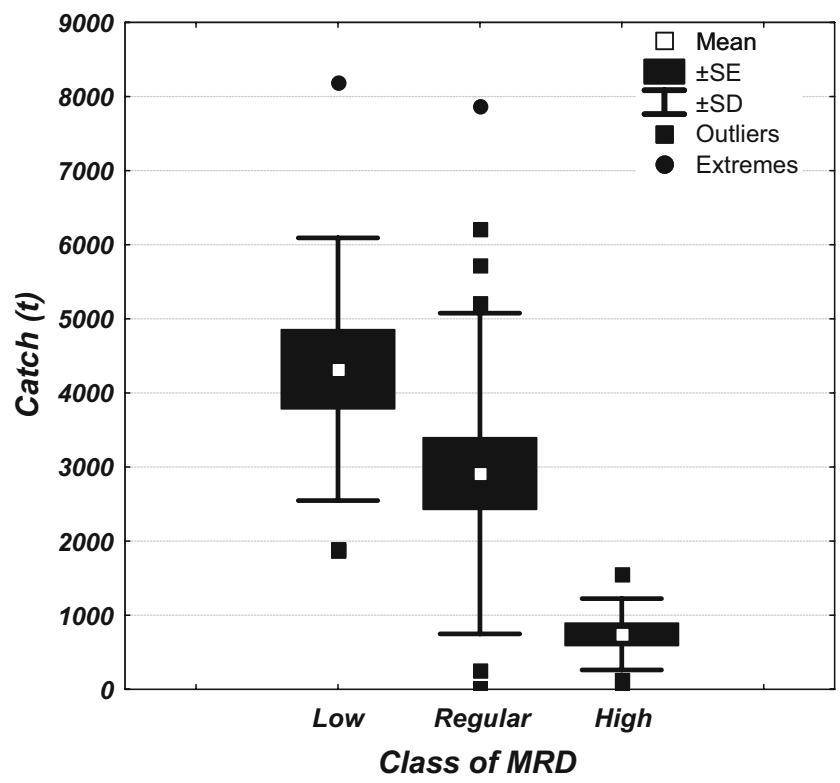

Fig. 4 Box plot of the TSC categorized by the type of runoff showing the mean, the standard deviation, and estimate errors. Low $\left(<1,000 \mathrm{~m}^{3} \mathrm{~s}^{-1}\right)$, regular $\left(1,000 \mathrm{~m}^{3} \mathrm{~s}^{-1}<\mathrm{MRD}<2,000 \mathrm{~m}^{3} \mathrm{~s}^{-1}\right)$, and high $\left(>2,000 \mathrm{~m}^{3} \mathrm{~s}^{-1}\right)$. Differences in the mean of TSC for low and high classes of river discharges are highly significant $(p<0.01)$

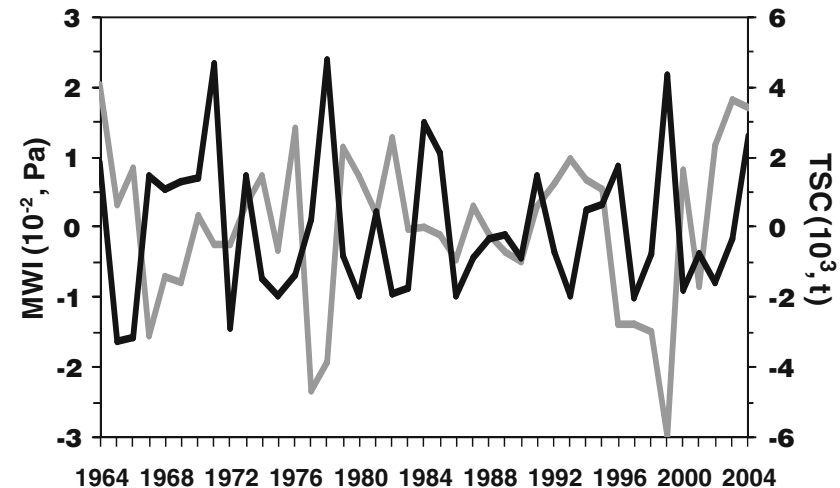

Fig. 5 Time series of TSC (black) and mean wind index (MWI, gray). Trend was removed in both series

favorable river discharge conditions to the occurrence of SW winds. This is a distinguished characteristic of La Niña years and is caused by the passage of successive meteorological cold fronts over the area. It disturbs the seasonal patterns of the wind field, of the coastal currents, and also of the southward larval transport.

Spectral analysis of the original time series of monthly averaged river discharge and pink shrimp catch data (Fig. 7a, b) indicated that the most energetic band was centered in the annual signal (12 months) followed by interannual variations having periods of 33 to 40 months and 84 months.

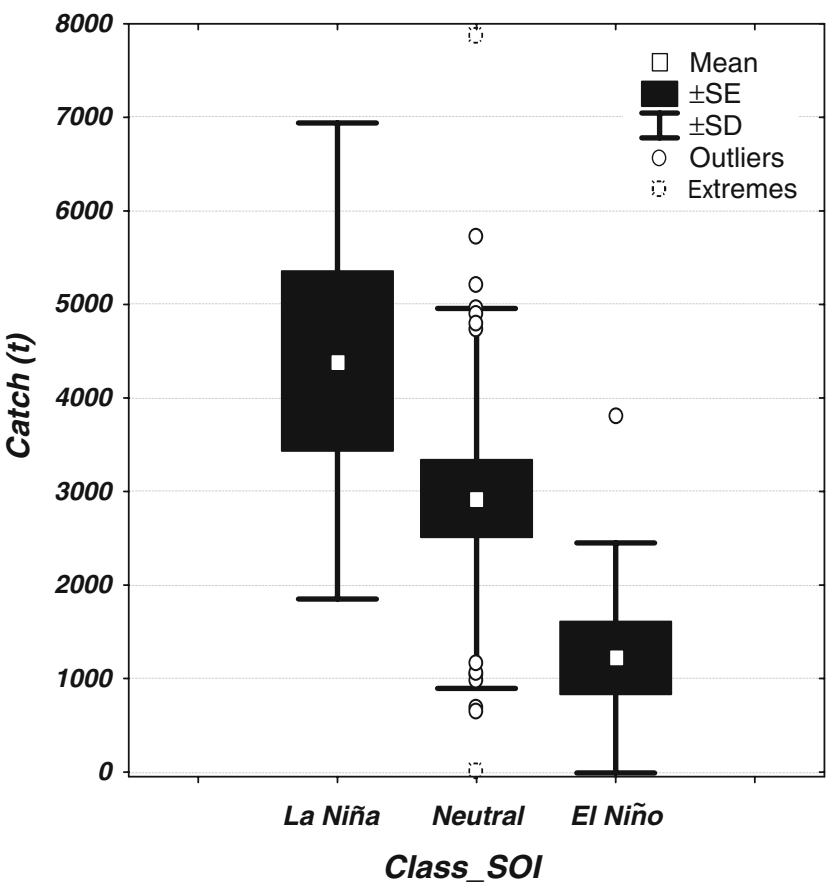

Fig. 6 Box plot of pink shrimp catch, categorized by type of ENSO event showing the mean and the standard and estimate errors. Differences in the mean of TSC for El Niño and La Niña events are highly significant $(p<0.01)$ 

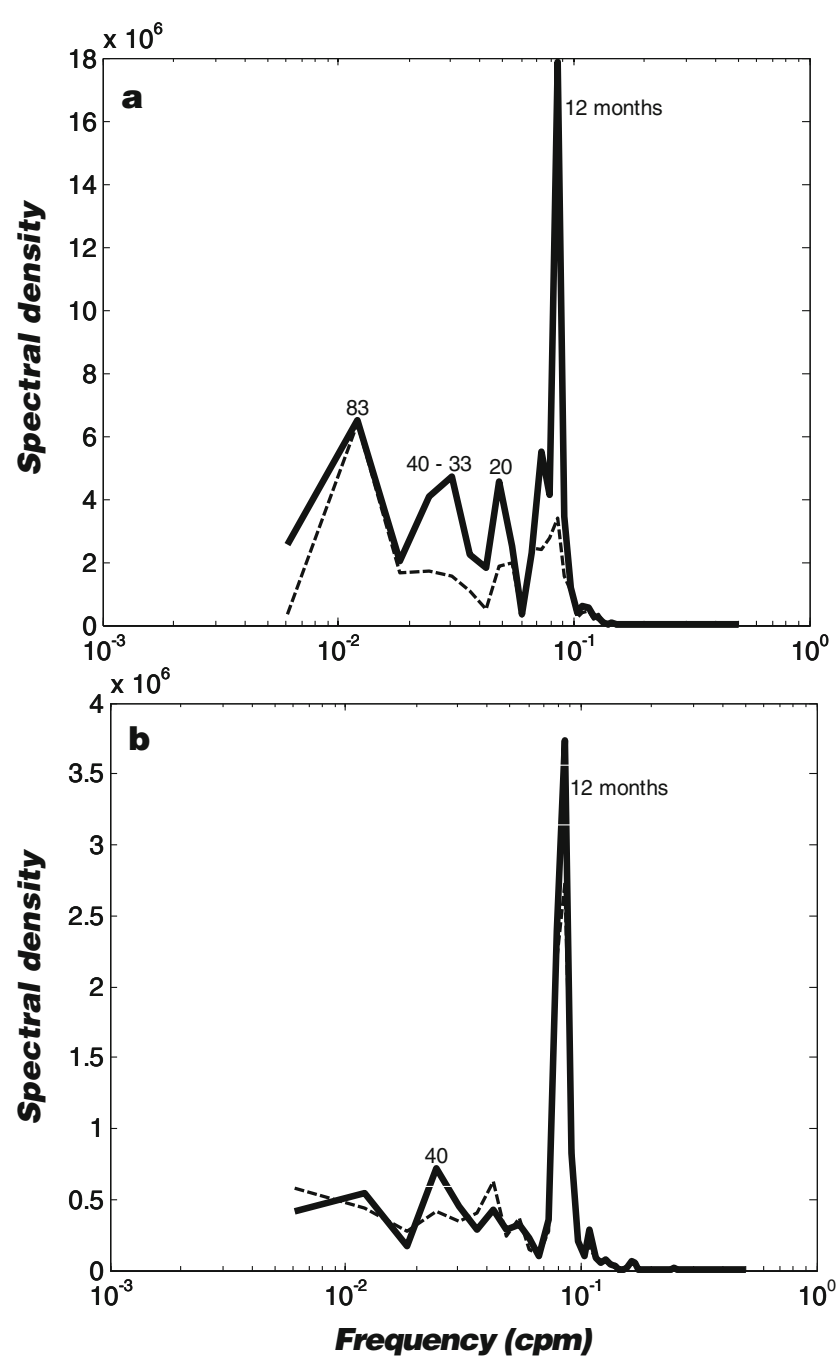

Fig. 7 Spectral analysis of river discharge (a) and pink shrimp catches (b). Dotted line indicates 95\% significance level

When looking at the general trends of river discharge (MRD) and pink shrimp catches (TSC; Fig. 8a, b) it is possible to conclude that river discharge is increasing at a rate of $20 \mathrm{~m}^{3} \mathrm{~s}^{-1}$ year ${ }^{-1}$, while pink shrimp catches are decreasing at a rate of 57 annual tons per year.

\section{Discussion and Conclusions}

River and Wind Effects

This study confirms that the river flow plays a decisive role in the conditions that will determine the entrance of pink shrimp larvae into PL. When the mean discharge of Jacuí, Taquarí, and Camaquã rivers for the period ranging from September to December is higher than $2,000 \mathrm{~m}^{3} \mathrm{~s}^{-1}$, it can by itself generate a seaward flow strong enough to block the entrance of larvae and salt water. It will cause a drop in pink shrimp production during the following year. For river discharge lower than $1,000 \mathrm{~m}^{3} \mathrm{~s}^{-1}$, the possibilities of above-average catches increase because in this situation even light SW $\left(>5 \mathrm{~m} \mathrm{~s}^{-1}\right)$ winds associated with the passage of meteorological fronts can force landward currents. On the other hand, the large standard deviation observed in Fig. 4 for the regular discharge class $\left(1,000 \mathrm{~m}^{3} \mathrm{~s}^{-1}<\mathrm{MRD}<2,000 \mathrm{~m}^{3} \mathrm{~s}^{-1}\right)$, indicates that the success of larvae entry in the period under normal flow conditions will depend on the favorable combination of river flow and wind conditions. If this period is dominated by NE winds, which also means a reduced number of meteorological front passages, a seaward flow will still be sustained affecting the entrance of larvae. This is a usual situation during spring.

The inverse response that pink shrimp catches present with respect to freshwater input in the PL is opposite to what has been observed in other estuaries. Anomalous higher shrimp catches registered in Lake Bourgne and Mississippi Sound during a high runoff period were caused by the nutrient enrichment associated with high river discharge (Kutkuhn 1966). Erhardt and Legault (1999) also found a positive relationship between precipitation rates and pink shrimp (Farfantepenaeus duorarum) recruitment. Moreover, they observed a reduction in pink shrimp recruitment during an intense drought period. The same trend was observed for benthic meio and macrofauna populations of Guadalupe and Nuece estuaries (Montagna and Kalke 1992). Another example is given by the decline in white shrimp in Louisiana and Texas estuaries during a drought, which was explained by the lethality of high salinity waters to juvenile shrimps (Kutkuhn 1966).
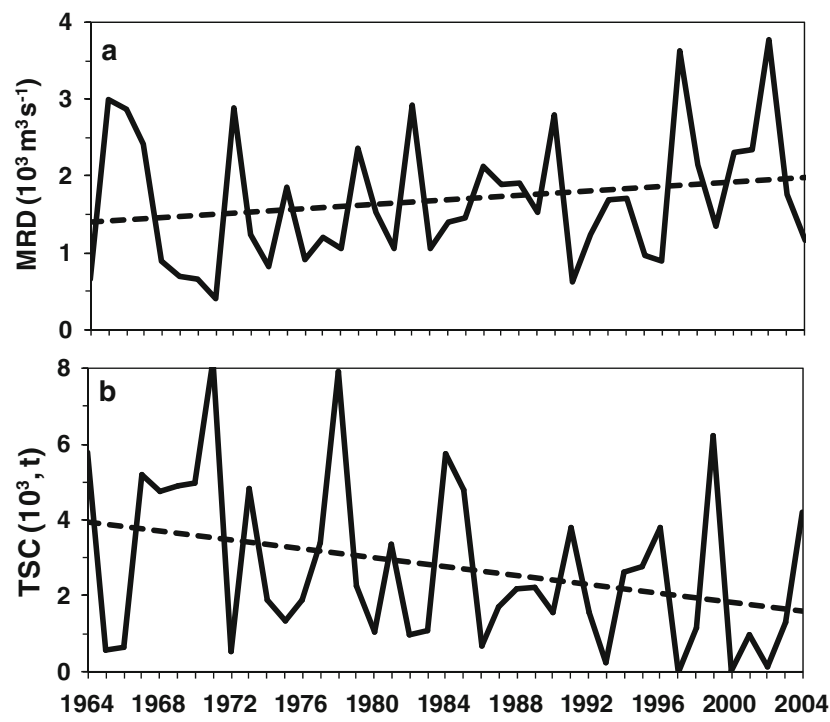

Fig. 8 Time series of MRD (a) and TSC (b). Dotted lines represent the linear trends 
The main factor that can account for the observed differences between the PL and the already cited ecosystems is the morphology of this lagoon. While in most estuaries the cross-sectional area increases seaward, the PL is a choked coastal system placed in a temperate climatic area. Its cross-sectional area decreases from $200,000 \mathrm{~m}^{2}$ in the inner parts to less than $10,000 \mathrm{~m}^{2}$ near the entrance (Möller and Castaing 1999). The choking of the PL was enhanced in the beginning of the last century when two convergent $4 \mathrm{~km}$ long jetties (waterbreakers) were built at the entrance to keep it clear for navigation (Motta 1969). In the area along the jetties, the width of the channel is reduced from $2 \mathrm{~km}$ to $0.7 \mathrm{~km}$. During strong flood periods, the circulation of this lagoon is entirely driven by river discharge, and a residual seaward flow is the dominant feature. The great reduction in the cross-sectional area near the lagoon mouth intensifies this circulation pattern. Therefore, under strong river runoff conditions, even SW wind events cannot reverse the outgoing flow, which avoids the entrance of salt water and larvae. In this scenario, all the richness that otherwise river water would bring to the estuary is transferred to the coastal zone, enhancing its productivity (Ciotti et al. 1995). When the seaward flow is momentarily reversed by very strong SW winds, those larvae that succeed to enter into the estuary are flushed out or die due to the fast decrease in salinity. According to Marchiori (1983), they cannot stand salinity lower than 3 .

During low to moderate runoff periods, the wind-driven circulation can play its role. Under such conditions, SW winds produce a landward flow, which will introduce the available shrimp larvae into the lagoon. The mixing of salt and freshwater forms an estuarine area that can reach up to $70 \mathrm{~km}$ from the entrance (Möller and Castaing 1999) or even farther in very dry years, such as the 1988 La Niña (Möller and Castaing 1999; Odebrecht et al. 2005). This provides a more stable environment, where the megalopa larvae can grow and complete their development.

Another possible effect of the wind on the catches is related to its action along the continental shelf that might interfere in the larval transport from the spawning area to their nursery grounds. The spawning area is located on the shelf region about $600 \mathrm{~km}$ north of the PL entrance, therefore the larvae must be transported by southward coastal currents. The importance of winds driving circulation and water mass distribution along southern Brazil and Uruguay continental shelves have been discussed in several recent studies (Zavialov et al. 2002, Piola et al. 2005, Möller et al. 2008 and Palma et al. 2008). These researches have demonstrated that currents in the inner and mid shelf areas are wind dominated and are likely to present seasonal and interannual variability. In spring and summer, but also during El Niño years (Piola et al. 2005), dominant NE winds force the southward coastal current system. Howev- er, in some exceptional periods, mainly La Niña years, the passage of frontal systems over the area is increased, and SW winds are dominant (Barros et al. 2002; Piola et al. 2005). Under these conditions, a northward residual flow will be induced over the continental shelf, and it will act against the larval transport towards the entrance of the PL and to Uruguayan coastal lagoons (Fabiano and Santana 2006). As a result, a low stock of recruits will be available to local fishermen.

The wind-driven circulation over the shelf off Chesapeake Bay was accounted as an important mechanism for the dispersion and recruitment of crab larvae (Roman and Boicourt 1999). However, for the southern Brazilian shelf, further studies focusing on understanding the larval dispersal pathways and rates of penetration into the PL estuary are needed.

\section{Interannual Variability and Longer-Term Trends}

Apart from producing significant impact on fish assemblage of the PL (Garcia et al. 2001; 2003), ENSO anomalies can have different impacts on shrimp catches in this area. It is well documented (Grimm et al. 1998; 2000) that southern Brazil presents a strong and consistent precipitation anomaly tied to these events. In Uruguay and Rio Grande do Sul, wet/dry anomalies are observed in late spring-early summer with a positive/negative peak in November during El Niño/La Niña years (Diaz et al. 1998, Grimm et al. 1998). Following it, the effect of El Niño is mainly tied with the large increase of river discharge, and its prolonged effect is coincident with the critical period for larvae entry. On the other hand, maximum values of TSC are observed during La Niña years. However, the large standard deviations presented by the pink shrimp catches are an indicator that river discharge is unlikely to be the only factor controlling it. An additional factor can be the strength of the ENSO event, which determines the intensity of its results (Dracup and Kahya 1994). Another mechanism can be related to wind anomalies associated with ENSO events, since SW winds dominate interannual variability during La Niña (Barros et al. 2002; Piola et al. 2005). It enhances the ingress of salt water into the PL; however, it opposes the southward larval transport.

Spectral analysis of river flow and shrimp production indicate that peaks center at 33 to 40 months and at 83 months, which are related to the periodicity of ENSO events. These interannual signals were also observed in analysis of the Uruguay River discharge data (Robertson and Mechoso 1998; Krepper et al. 2003). This hydrographical basin is adjacent to the PL basin and subject to the same climatic conditions.

The long-term trend indicated in Fig. 8 shows an increase in river discharge of the order of $20 \mathrm{~m}^{3} \mathrm{~s}^{-1}$ year ${ }^{-1}$. 
The same trend was observed for the Uruguay River after the mid-1960s by Genta et al. (1998) and Krepper et al. (2003). The streamflow increasing rate can be one of the factors that can contribute to the observed decrease in pink shrimp catches at a rate of 57 tons per year. Overfishing (D'Incao et al. 2002) and higher levels of fish predation on the source population may also be among the causes of such behavior.

Acknowledgments The authors would like to thank: (a) the Rio Grande office of the Instituto Brasileiro de Meio Ambiente (IBAMA) and the Agência Nacional de Águas (ANA) for providing, respectively, shrimp catches and river discharge data; (b) the Conselho Nacional de Desenvolvimento Científico e Tecnológico (CNPq) for grants 302173/2004-8 (OMJ), 300662/ 2005-0 (JPC) and IC/PIBIC/FURG (ACV). This paper is a contribution from the South Atlantic Climate Change consortium that has been funded by the Inter-American Institute for Global Change Research (IAI) through grants CRN061 and CRN2076. The IAI is supported by the US National Science Foundation grant GEO-0452325. Dr. Tabajara Almeida and two anonymous reviewers helped to increase the quality of the manuscript.

\section{References}

Abreu, P.C. and J.P. Castello. 1997. Estuarine-Marine Interactions. In Subtropical Convergence Environments. The coast and sea in the Southwestern Atlantic, ed. U.C. Seeliger, C. Odebrecht, and J.P. Castello, 179-182. Berlin: Springer-Verlag.

Agência Nacional de Águas. 2007. Séries históricas. http://hidroweb. ana.gov.br, acessed 6 March 2007.

Australian Bureau of Meteorology. 2007. S.O.I. Archives - 1876 to present. http://www.bom.gov.au/climate/current/soihtm1.shtml, accessed 12 July 2007.

Barros, V.R., A.M. Grimm, and M.E. Doyle. 2002. Relationship between temperature and circulation in Southwestern South America and its influence from El Niño and La Niña events. Journal of the Meteorological Society of Japan 80: 21-32. doi:10.2151/jmsj.80.21.

Berlato, M.A., and D.C. Fontana. 2003. El Niño e La Niña. Impactos no clima, na vegetação e na agricultura do Rio Grande do Sul. Porto Alegre: Editora da Universidade Federal do Rio Grande do Sul (UFRGS).

Castello, J.P. 1985. La ecologia de los consumidores del estuario da Lagoa dos Patos, Brasil. In Fish Community Ecology in Estuaries and Coastal Lagoons: Towards an Ecosystem Integration, ed. A. Yañes-Arancibia, 383-406. Mexico: Universidad Nacional Autonoma de Mexico Press.

Castello, J.P. and O.O. Möller Jr. 1978. On the relationship between rainfall and shrimp production in the estuary of the Patos Lagoon (Rio Grande do Sul, Brazil). Atlântica 3: 67-74.

Ciotti, A.M., C. Odebrecht, G. Fillmann, and O.O. Möller. 1995. Freshwater outflow and Subtropical Convergence influence on phytoplankton biomass on the southern Brazilian continental shelf. Continental Shelf Research 15: 1737-1756. doi:10.1016/ 0278-4343(94)00091-Z.

Delevedove, G.C.D. 1996. Genética populacional do camarão-rosa Penaeus paulensis (Decapoda: Penaeidae) na região estuarina da Lagoa dos Patos, no Rio Grande do Sul e litoral de Santa Catarina. MSc. dissertation, Fundação Universidade Federal do Rio Grande, Rio Grande, Rio Grande do Sul, Brasil.
Diaz, A.F., C.D. Studzinski, and C.R. Mechoso. 1998. Relationships between precipitation anomalies in Uruguay and southern Brazil and sea surface temperature in the Pacific and Atlantic oceans. Journal of Climate 11: 251-271. doi:10.1175/1520-0442(1998) $011<0251$ :RBPAIU $>2.0$.CO;2.

D'Incao, F. 1991. Pesca e biologia de Penaeus paulensis na Lagoa dos Patos, RS. Atlântica 13: 159-169.

D'Incao, F., H. Valentini, and L.F. Rodrigues. 2002. Avaliação da pesca de camarões nas regiões sudeste e sul do Brasil. Atlântica 24(2): 103-116.

Dracup, J.A. and E. Kahya. 1994. The relationship between U.S. streamflow and La Niña events. Water Resources Research 30: 2133-2141.

Emery, W.J. and R.E. Thomson. 1997. Data Analysis Methods in Physical Oceanography. Oxford: Pergamon.

Erhardt, N.M. and C.M. Legault. 1999. Pink shrimp (Farfantepenaeus duorarum), recruitment variability as an indicator of Florida Bay dynamics. Estuaries 22: 471-483.

Fabiano, G. and O. Santana. 2006. Las pesquerías en las lagunas costeras salobres de Uruguay. In Bases para la conservación y manejo de la costa uruguaya, ed. R. Menafra, L. Rodríguez-Gallego, F. Scarabino, and D. Conde, 557-565. Montevideo: Vida Silvestre.

Garcia, A.M., J.P. Vieira, and K.O. Winemiller. 2001. Dynamics of the shallow-water fish assemblage of the Patos Lagoon estuary (Brazil) during cold and warm ENSO episodes. Journal of Fish Biology 59: 1218-1238.

Garcia, A.M., J.P. Vieira, and K.O. Winemiller. 2003. Effects of the 1997-1998 El Niño on the dynamics of the shallow-water fish assemblage of the Patos Lagoon estuary (Brazil). Estuarine and Coastal Shelf Science 57: 489-500.

Genta, J.L., G. Perez-Iribarren, and C.R. Mechoso. 1998. A recent increasing trend in the streamflow of rivers of Southeastern South America. Journal of Climate 11: 2858-2862.

Grimm, A., S.E.T. Ferraz, and J. Gomes. 1998. Precipitation Anomalies in Southern Brazil associated with El Niño and La Niña Events. Journal of Climate 11: 2863-2880.

Grimm, A.M., V.R. Barros, and M.E. Doyle. 2000. Climate variability in Southern South America associated with El Niño and La Niña events. Journal of Climate 13: 35-58.

Haimovici, M., J.P. Castello, and C.M. Vooren. 1996. Fisheries, p. 183-196. In Subtropical Convergence Environments, the Coast and Sea in the Southwestern Atlantic, ed. U.C. Seeliger, C. Odebrecht, and J.P. Castello, 183-196. Berlin: Springer-Verlag.

Haimovici, M., M. Vasconcellos, D.C. Kalikosoki, P. Abdalah, J.P. Castello, and D. Hellebrandt. 2006. Diagnóstico da Pesca no Litoral do Estado do Rio Grande do Sul. In A Pesca Marina e Estuarina do Brasil no Início do Século XXI: recursos, tecnologias, aspectos sócio-econômicos e institucionais, eds. V. J. Isaac, A.S. Martins, M. Haimovici and J.M. Andriguetto, 157180. Belém, Universidade Federal do Pará (UFPA).

Kalikoski, D.C., M. Vasconcellos, and M.L. Lavkulich. 2002. Fitting institutions and ecosystems: the case of artisanal fisheries management in the Patos lagoon. Marine Policy 26 (3): 179-196.

Kistler, R., E. Kalnay, W. Collins, et al. 2001. The NCEP-NCAR 50 year reanalysis: Monthly means CD-ROM and documentation. Bulletin of the American Meteorological Society 82: 247-267.

Kjerfe, B. 1986. Comparative oceanography of coastal lagoons, p. 63 81. In Estuarine Variability, ed. D.A. Wolfe, 63-81. New York: Academic Press.

Kousky, V.E. and I.F. Cavalcanti. 1984. Eventos Oscilação do Sul - El Niño: Características, evolução e anomalias de precipitação. Ciência e Cultura 36: 1888-1899.

Krepper, C.M., N.O. Garcia, and P.D. Jones. 2003. Interannual variability in the Uruguay River basin. International Journal of Climatology 23: 103-115. 
Kutkuhn, J.H. 1966. The role of estuaries in the development and perpetuation of commercial shrimp resources. In A Symposium on Estuarine Fisheries. American Fisheries Society 3: 16-36.

Marchiori, M.A. 1983. Estudos para o desenvolvimento do cultivo do camarão-rosa Penaeus paulensis no estuário da Lagoa dos Patos, Rio Grande, RS. Proceedings of the III Simpósio Brasileiro de Aquicultura, São Carlos, Brazil.

Mechoso, C.R. and G. Pérez-Iribarren. 1992. Streamflow in southeastern South America and the Southern Oscillation. Journal of Climate 5: 1535-1539.

Möller, O.O. 1996. Hydridynamique de la Lagune dos Patos $\left(30^{\circ} \mathrm{S}\right.$, Brésil). Mesures et modélisation. Ph.D thesis. Université Bordeaux I, France.

Möller, O.O. and P. Castaing. 1999. Hydrographical Characteristics of the Estuarine Area of Patos Lagoon ( $30^{\circ} \mathrm{S}$, Brazil). In Estuaries of South America. Their Geomorphology and Dynamics, ed. G. M.E. Perillo, M.C. Piccolo, and M.P. Quivira, 83-100. Berlin: Springer-Verlag.

Möller, O.O., P. Casting, J.C. Salomon, and P. Lazure. 2001. The Influence of Local and Non-Local Forcing Effects on the Subtidal Circulation of Patos Lagoon. Estuaries 24: 297-311.

Möller, O.O., P. Castaing, E.H.L. Fernandes, and P. Lazure. 2007. Tidal frequency dynamics of a southern Brazil coastal lagoon: choking and short period forced oscillations. Estuaries and Coasts 30: 311-320.

Möller, O.O., A.R. Piola, A.C. Freitas, and E.J.D. Campos. 2008. The effects of river discharge and seasonal winds on the shelf of the southeastern South America. Continental Shelf Research 28: $1607-1624$.

Montagna, P.A. and R.D. Kalke. 1992. The effect of freshwater inflow on meiofaunal and macrofaunal populations in Guadalupe and Nuece estuaries, Texas. Estuaries 15: 307-326.

Moron, V., S. Bigot, and P. Roucou. 1995. Rainfall variability in subequatorial America and Africa and relationships with the main sea-surface temperature modes (1951-1990). International Journal of Climatology 15: 1297-1322.

Motta, V.F 1969. Relatório diagnóstico sobre a melhoria e o aprofundamento do canal de acesso pela barra do Rio Grande. Tech. Report. Instituto de Pesquisas Hidráulicas, Universidade Federal do Rio Grande do Sul., Brazil.

Muelbert, J.H., and G. Weiss. 1991. Abundance and distribution of fish larvae in the channel area of the Patos Lagoon estuary, Brazil. National Oceanic and Atmospheric Administration Technical Report, National Marine Fisheries Service 95:43-54.

Odebrecht, C., P.A. Abreu, O.O. Möller, L.F. Niencheski, and L.C. Torgan. 2005. Drought effects on pelagic properties in the shallow and turbid Patos Lagoon, Brazil. Estuaries 28: 675-685.
Palma, E.D., R.P. Matano, and A.R. Piola. 2008. A numerical study of the Southwestern Atlantic Shelf circulation: stratified ocean response to local and offshore forcing. Journal of Geophysical Research 13: C11010. doi:10.1029/2007JC004720.

Piola, A.R., R.P. Matano, E.D. Palma, O.O. Möller, and E.J.D. Campos. 2005. The influence of the Plata River discharge on the western South Atlantic shelf. Geophysical Research Letters 32: L01603. doi:10.1029/2004GL021638.

Ramp, S.R., L.K. Rosenfeld, T.D. Tisc, and M.R. Hicks. 1997. Moored observations of the current and temperature structure over the continental slope off central California. A basic description of the variability. Journal of Geophysical Research 102: 22877-22902.

Reis, E.G. and F. D'Incao. 2000. The present status of artisanal fisheries of extreme Southern Brazil: an effort towards community-based management. Ocean and Coastal Management 43: 585-595.

Robertson, A.W. and C. Mechoso. 1998. Interannual and decadal cycles in river flows of Southeastern South America. Journal of Climate 11: 2570-2581.

Roman, M. and W. Boicourt. 1999. Dispersion and recruitment of crab larvae in the Chesapeake Bay plume: physical and biological control. Estuaries 22: 563-574.

Ropelewski, C.F. and M.S. Halpert. 1987. Global and regional scale precipitation patterns associated with the El Niño/ Southern Oscillation. Monthly Weather Review 115: 1606-1626.

Trenberth, K., J. Olson, and W. Large. 1989. A Global Ocean Wind Stress Climatology Based on ECMWF Analyses, Tech. Rep. NCAR/TN- 338+STR, Natl. Center for Atmospheric Research, Boulder, Colorado.

Valentini, H., F. D'Incao, L.F. Rodrigues, J.E. Rebelo Neto, and E. Rahn. 1991. Análise da pesca do camarão-rosa (Penaeus brasiliensis e Penaeus paulensis) nas regiões sudeste e sul do Brasil. Atlântica 13: 143-157.

Vaz, A.C., O.O. Möller, and T.L. Almeida. 2006. Uma nota sobre os afluentes da Lagoa dos Patos. Atlântica 28: 13-23.

Vieira, J.P. and J.P. Castello. 1996. Fish Fauna. In Subtropical Convergence Environments, the Coast and Sea in the Southwestern Atlantic, ed. U.C. Seeliger, C. Odebrecht, and J.P. Castello, 56-61. Berlin: Springer-Verlag.

Zavialov, P., O.O. Möller, and E.J.D. Campos. 2002. First direct measurements of currents on the continental shelf of southern Brazil. Continental Shelf Research 22: 1975-1986.

Zenker, H.H. and Agnes, 1977. Distribuição do camarão rosa Penaeus brasiliensis e Penaeus paulensis ao longo da costa sudeste e sul do Brasil. Séries Doc. Téc. Brasília. SUDEPE-PDP 21:1-105. 